AperTO - Archivio Istituzionale Open Access dell'Università di Torino

\title{
Acute HIV infection: Improved algorithms for HIV testing.
}

\section{This is the author's manuscript}

Original Citation:

Availability:

This version is available http://hdl.handle.net/2318/1508423

since 2016-06-24T09:25:55Z

Published version:

DOI:10.1016/j.jcv.2014.12.007

Terms of use:

Open Access

Anyone can freely access the full text of works made available as "Open Access". Works made available under a Creative Commons license can be used according to the terms and conditions of said license. Use of all other works requires consent of the right holder (author or publisher) if not exempted from copyright protection by the applicable law. 
This is a pre-copyedited, author-produced PDF of an article accepted for publication in Journal of Clinical Virology following peer review. The version of record J Clin Virol. 2015

Feb;63:51-2. doi: 10.1016/j.jcv.2014.12.007. Epub 2014 Dec 12. is available online at: http://www.journalofclinicalvirology.com/article/S13866532(14)00469-7/abstract 


\section{Acute HIV Infection: Improved algorithms for HIV testing}

Partly presented at the $20^{\text {th }}$ International AIDS Conference (AIDS 2014), Melbourne, Australia, 20-25 July 2014, as poster presentation, abstract number A-641-0087-02054

Keywords: Acute HIV Infection, HIV testing, Western Blot, HIV-RNA

Identification of Acute HIV Infection (AHI) has direct implications for the safety of blood products, HIV prevention, due to patient high infectiousness and HIV treatment. Antiretroviral therapy at this stage allows for potential immunological and viral advantages and latent reservoirs reduction [1]. Recently published CDC recommendations for HIV testing suggest that $4^{\text {th }}$ generation $(4 \mathrm{thG})$ immunoassays (IAs) for the combined detection of HIV p24-antigen and HIV-antibody should become the standard of care for HIV testing because they are more sensitive than $3^{\text {rd }}$ generation assays [2,3]. The same guidelines suggest that confirmation of HIV screening reactivity should be assessed by the detection of viral genome (HIV-RNA) instead with Western Blot (WB) due to the significant less sensitivity of WB in the early stages of HIV infection. In contrast to other 4thG IAs, a recently CE approved HIV assay, the LIAISON-XL Murex HIV $\mathrm{Ab} / \mathrm{Ag}$ (DiaSorin, Saluggia, Italy) offers the advantage of a signal discrimination between HIV-p24 and HIV-antibody reactivity.

In the year 2013, at the laboratory of Microbiology and Virology, Infectious Diseases Department, University of Torino, Italy, 15,412 HIV tests were routinely performed (HIV infection rate: $1.8 \%$ ), with the following procedure: HIV screening with 4thG ARCHITECT HIV Ag/Ab Combo (Abbott Diagnostics, Rome, I), re-testing reactive samples with LIAISON-XL, confirmation of screening results with WB (HIV-1, BIO-RAD, Milan, I) and/or HIV-RNA (CAP/CTM HIV-1, v2.0, Roche Molecular Diagnostic, Branchburg, NJ, USA). ARCHITECT and LIAISON-XL analytical sensitivity according to WHO p24 (NIBSC 90/636) and French National Reference (SFTS 2007) HIV standards is 17.8 and $22 \mathrm{pg} / \mathrm{ml}$, respectively (1.032 and $0.873 \mathrm{IU} / \mathrm{ml}$ ) [4]. Following latest CDC recommendations, we reviewed AHI identified in the year 2013 (15 patients, corresponding to $5.4 \%$ of new HIV infections) defined by a positive HIV-RNA and a nonreactive/indeterminate WB [1]. 
The two 4thG IAs correctly identified AHI infection in all patients (average age: 40 years \pm 11 ; CD4+ cell count: $477 \pm$ 209/uL; HIV-RNA median level: 942,295, range 95,295 - >10 million copies/mL). By LIAISON-XL HIV-antibodies and p24 were positive in 10/15 and 11/15 AHI, respectively (sensitivity: 67 and 73\%). Fiebig stage II and III [5] were identified in 5/5 and 3/3 patients (HIV-RNA > 500,000 and > 300,000 copies/mL, respectively). WB was negative in Fiebig stage II and III patients ( $\mathrm{n}=8)$ and indeterminate in Fiebig stage IV (7 patients) (Table 1). p24 correlation with HIV-RNA was good (r=0.822, $\mathrm{p}=0.0002,95 \%$ CI $0.535-0.939)$.

In conclusion, 4thG IAs are very sensitive for the detection of AHI and they enhance the early detection of HIV infection during the acute phase, when substantial HIV transmission occurs, thus representing an important advance in HIV testing to address HIV public health burden. Confirmation of their results should not include WB, but the detection of HIV-RNA due to the lack of WB sensitivity in the early stages of HIV infection. Recently commercialized 4thG IAs allowing signal discrimination between reactivity due to p24 and HIV antibody offer the advantage of a better classification of AHI. This is certainly an added value in situations where HIV-RNA testing is not available.

Word count: 499

\section{Funding}

None.

\section{Competing interests}

None declared.

\section{Ethical approval}

Not required.

\section{References}

[1] Cohen MS, Shaw GM, McMichael AJ, Haynes BF. Acute HIV-1 infection. N Engl J Med 2011; 364:1943-54. doi: 10.1056/NEJMra1011874 
[2] Branson BM, Owen SM, Wesolowski LG, Bennett B, Werner BG, Wroblewski KE, Pentella MA. Laboratory Testing for the Diagnosis of HIV Infection: Updated Recommendations. Centers for Disease Control and Prevention and Association of Public Health Laboratories. Available at http://dx.doi.org/10.15620/cdc.23447. Published June 27, 2014

[3] Masciotra S, Smith AJ, Youngpairoj AS, Sprinkle P, Miles I, Sionean C, Paz-Bailey G, Johnson JA, Owen SM. Evaluation of the CDC proposed laboratory HIV testing algorithm among men who have sex with men (MSM) from five US metropolitan statistical areas using specimens collected in 2011. J Clin Virol 2013;58 Suppl 1:e8-e12. doi: 10.1016/j.jcv.2013.09.002

[4] Ly TD, Plantier JC, Leballais L, Gonzalo S, Lemée V, Laperche S. The variable sensitivity of HIV Ag/Ab combination assays in the detection of p24 Ag according to genotype could compromise the diagnosis of early HIV infection. J Clin Virol 2012;55: 121-7. doi: 10.1016/j.jcv.2012.06.012

[5] Cohen MS, Gay CL, Busch MP, Hecht FM. The detection of acute HIV infection. J Infect Dis 2010;202 Suppl 2:S270-7. doi: $10.1086 / 655651$

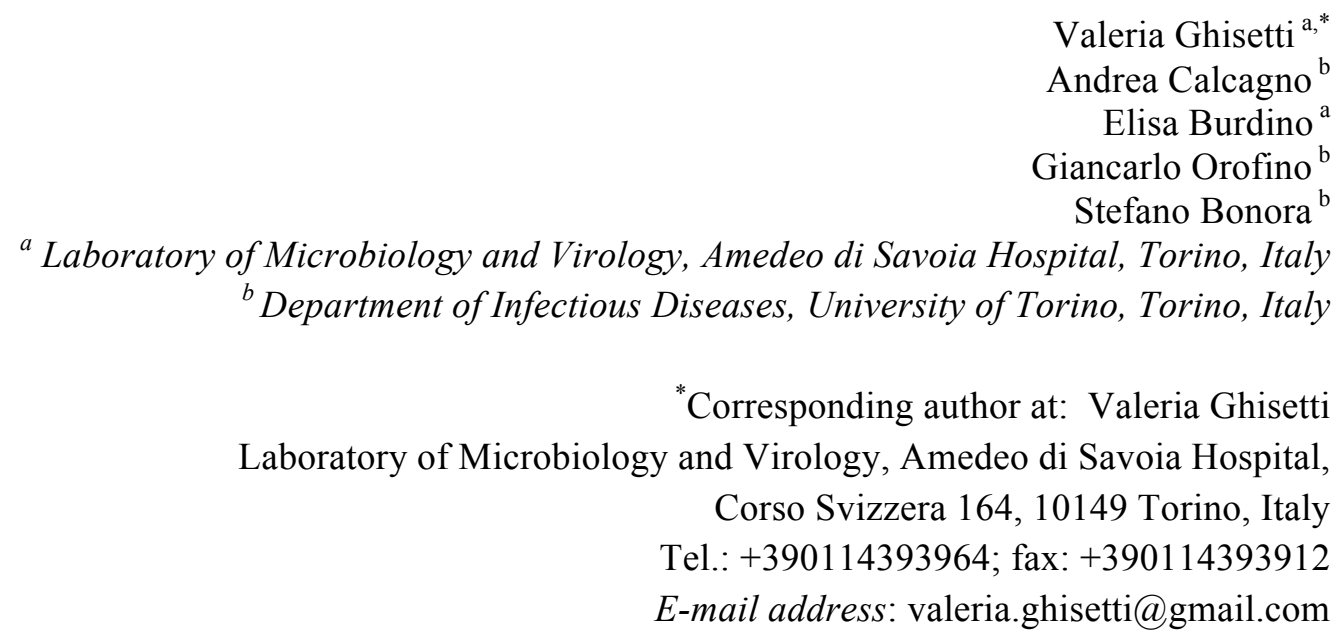

25 November 2014 
Table 1

Characteristics of the 15 patients with AHI.

\begin{tabular}{|c|c|c|c|c|c|c|c|c|c|c|c|}
\hline ID & $\begin{array}{l}\text { Age } \\
\text { years }\end{array}$ & Sex & Risk Factor & $\mathrm{CD} 4 / \mathrm{ul}$ & $\begin{array}{c}\text { ARCHITECT } \\
\text { Ag/Ab Combo } \\
\text { S/CO ratio }\end{array}$ & $\begin{array}{l}\text { LIAISON- } \\
\text { XL } \\
\text { HIV-p24 } \\
\text { S/CO ratio }\end{array}$ & $\begin{array}{l}\text { LIAISON- } \\
\text { XL } \\
\text { Antibody } \\
\text { S/CO ratio }\end{array}$ & $\begin{array}{l}\text { HIV-RNA } \\
\text { copies/mL }\end{array}$ & $\begin{array}{l}\text { Fiebig } \\
\text { stages }\end{array}$ & $\begin{array}{c}\text { HIV } \\
\text { GENOTYPE }\end{array}$ & WB \\
\hline 1 & 37 & M & MSM & 222 & 1.74 & 2.6 & 160 & 586,295 & III & B & Negative \\
\hline 2 & 31 & M & MSM & 502 & 1.62 & Negative & 25 & 336,000 & III & B & Negative \\
\hline 3 & 31 & M & MSM & 377 & 2.12 & 2 & Negative & 502,802 & II & B & Negative \\
\hline 4 & 50 & M & MSM & 561 & 41 & Negative & 56 & 301,154 & IV & $\mathrm{Na}$ & IND \\
\hline 5 & 42 & M & Etero/bisex & 270 & 28.9 & 29 & Negative & 740,881 & II & B & Negative \\
\hline 6 & 38 & $\mathrm{~F}$ & Etero/bisex & 749 & 92 & Negative & 22 & 95,295 & IV & B & IND \\
\hline 7 & 40 & M & MSM & 452 & 129 & 168 & Negative & $>10,000,000$ & II & B & Negative \\
\hline 8 & 37 & M & MSM & 788 & 35 & Negative & 43 & $1,802,927$ & IV & $\mathrm{Na}$ & IND \\
\hline 9 & 40 & M & MSM & 447 & 190 & 105 & 39 & $>10,000,000$ & III & B & Negative \\
\hline 10 & 45 & M & MSM & 566 & 88 & 1.25 & 41 & 288,769 & IV & B & IND \\
\hline 11 & 49 & M & MSM & 39 & 88 & 5.4 & 36 & $3,955,236$ & IV & CRF02_AG & IND \\
\hline 16 & 69 & M & MSM & 705 & 116 & 51 & Negative & $>10,000,000$ & II & A & Negative \\
\hline 13 & 25 & M & MSM & $\mathrm{Na}$ & 373 & 1.85 & 106 & 410,000 & IV & B & IND \\
\hline 14 & 48 & M & MSM & 335 & 39 & 16 & 35 & $6,019,484$ & IV & B & IND \\
\hline 15 & 28 & M & MSM & 503 & 1.76 & 1.27 & Negative & $1,144,212$ & II & $\mathrm{Na}$ & Negative \\
\hline
\end{tabular}

ARCHITECT and LIASON-XL non reactive samples for S/CO (Cut-off) ratio $\leq 1$.

IND: Indeterminate WB pattern according to CDC interpretative criteria.

Na: Not available. 